\title{
Helmet-Wearing Practices and Barriers in Toronto Bike-Share Users: a Case-Control Study
}

\author{
Steven Marc Friedman, $\mathrm{MD}, \mathrm{MPH}^{*}{ }^{\dagger}$; Matthew Adamson, $\mathrm{BPHE}^{\dagger}$; Paula Cleiman, $\mathrm{BSc} \mathrm{MD}^{*}$; \\ Tamara Arenovich, BSc, MSc ${ }^{\dagger}$; Karolina Oleksak, BScE (Hons) ${ }^{\ddagger}$; Ishmael Michael Mohabir, BSc $^{\ddagger}$; \\ Robert Ta, BSc, MSc ; Kimberley Reiter, BMSc ${ }^{\text {I }}$
}

\section{ABSTRACT}

Background: Helmet use among bike-share users is low. We sought to characterize helmet-use patterns, barriers to helmet use, and cycling safety practices among bike-share users in Toronto.

Methods: A standardized survey of public bike-share program (PBSP) users at semi-random distribution of PBSP stations was undertaken. By maintaining a ratio of one helmet-wearer (HW): two non-helmet-wearers (NHW) per survey period, we controlled for location, day, time, and weather.

Results: Surveys were completed on 545 (180 HW, 365 NHW) unique users at 48/80 PBSP locations, from November 2012 to August 2013. More females wore helmets (F: $41.1 \%, \mathrm{M}: 30.9 \%$, $p=0.0423$ ). NHWs were slightly younger than HWs (NHW mean age 34.4 years vs HW $37.3, p=0.0018$ ). The groups did not differ by employment status, education, or income.

Helmet ownership was lower among NHWs (NHW: $62.4 \%$ vs HW: $99.4 \%, p<0.0001$ ), as was personal bike ownership (NHW: $65.8 \%$, vs HW: $78.3 \%, p=0.0026)$. NHWs were less likely to always wear a helmet on personal bikes (NHW: $22.2 \%$ vs HW: $66.7 \%, p<0.0001)$, and less likely to wear a helmet always or most of the time on PBSP (NHW: $5.8 \%$ vs HW: 92.3\%, $p<0.0001)$. Both groups, but more HWs, had planned to use PBSP when leaving their houses (HW: $97.2 \%$ vs NHW: $85.2 \%$, $p<0.0001$ ), primarily to get to work (HW: $88.3 \%$ vs NHW: $84.1 \%, p=0.19)$. NHWs were more likely to report that they would wear a helmet more (NHW: $61.4 \%$ vs HW: $13.9 \%$, $p<0.0001$ ), and/or cycle less (NHW: $22.5 \%$ vs HW: $4.4 \%$ ) if helmet use was mandatory.

Conclusions: PBSP users surveyed appear to make deliberate decisions regarding helmet use. NHWs tended to be male, slightly younger, and less likely to use helmets on their personal bikes. As Toronto cyclists who do not wear helmets on PBSP generally do not wear helmets on their personal bikes, interventions to increase helmet use should target both personal and bike-share users. Legislating helmet use and provision of rental helmets could improve helmet use among bike-share users, but our results suggest some risk of reduced cycling with legislation.
RÉSUMÉ

Contexte: Peu d'usagers des services de partage de vélos portent le casque. Aussi les auteurs ont-ils cherché à caractériser les habitudes du port du casque, les obstacles à son utilisation et les pratiques en matière de sécurité parmi les usagers du service de partage de vélos à Toronto.

Méthode: Une enquête normalisée a été menée parmi les usagers du programme public de partage de vélos (PPPV), à différentes stations, choisies selon une répartition semialéatoire. Les auteurs, en maintenant constant le rapport de un porteur de casque (PC)/deux non-porteurs de casques (NPC) par période d'enquête, ont neutralisé les variables relatives au lieu, au jour, à l'heure et au temps (conditions météorologiques).

Résultats: L'enquête a porté sur 545 (180 PC; 365 NPC) usagers différents, à 48/80 stations, de novembre 2012 à août 2013. Les femmes $(F)$ étaient plus nombreuses que les hommes $(H)$ à porter le casque (F: 41,1 \%; $H$ : 30,9 \%; $p=0,0423)$. Les NPC étaient un peu plus jeunes que les PC (NPC: 34,4 ans en moyenne contre [c.] PC: 37,3 ans en moyenne; $p=0,0018$ ). Par contre, il n'y avait pas de différence entre les groupes quant à la situation de l'emploi, aux études ou au revenu.

Le fait de posséder son propre casque était plus faible parmi les NPC (NPC: $62,4 \%$ c. PC: $99,4 \% ; p<0,0001$ ) que parmi les PC, tout comme le fait de posséder sa propre bicyclette (NPC: $65,8 \%$ c. PC: $78,3 \% ; p=0,0026$ ). Les NPC avaient moins tendance à toujours porter un casque sur leur bicyclette personnelle (NPC: $22,2 \%$ c. PC: $66,7 \% ; p<0,0001$ ) et à toujours ou presque toujours porter un casque sur les bicyclettes du PPPV (NPC: 5,8 \% c. PC: 92,3\%; $p<0,0001$ ). Dans les deux groupes, mais davantage dans celui des $\mathrm{PC}$, les cyclistes avaient prévu recourir au PPPV au départ de la maison (PC: $97,2 \%$ c. NPC: $85,2 \% ; p<0,0001$ ), surtout pour se rendre au travail (PC: $88,3 \%$ c. NPC: $84,1 \% ; p=0,19$ ). Les NPC étaient plus nombreux que les PC à indiquer qu'ils porteraient le casque plus souvent (NPC: $61,4 \%$ c. PC: $13,9 \%$, $p<0,0001$ ) et/ou qu'ils feraient moins de bicyclette (NPC: $22,5 \%$ c. PC: $4,4 \%$ ) si le port du casque devenait obligatoire.

From the *Department of Emergency Medicine, University Health Network, Toronto, ON; †Faculty of Medicine and $¥$ Faculty of Science, University of Toronto, Toronto, ON; §School of Medicine, Trinity College Dublin, Dublin, Ireland; and IFaculty of Medicine, University of Ottawa, ON.

Correspondence to: Dr. Steven Marc Friedman, Department of Emergency Medicine, University Health Network, RFE G S434, 200 Elizabeth Street, Toronto, Ontario M5G 2C4; E-mail: steven.friedman@uhn.ca 
Conclusions: Les usagers du PPPV ayant participé à l'enquête semblent avoir fait un choix délibéré quant au port du casque. Les NPC étaient en général des hommes, un peu plus jeunes que les $P C$ et les premiers avaient moins tendance que les seconds à porter un casque sur leur bicyclette personnelle. Comme les cyclistes qui ne portent pas de casque sur les bicyclettes du PPPV n'en portent généralement pas sur leur bicyclette personnelle à Toronto, les interventions visant à accroître le port du casque devraient viser autant les propriétaires de bicyclette personnelle que les usagers du service de partage de vélos. Toutefois, le fait d'imposer le port du casque et la fourniture de casques de location par voie législative pourrait certes améliorer le port du casque parmi les usagers du service de partage de vélos, mais, d'après les résultats de l'enquête, cela pourrait aussi avoir pour conséquence de diminuer l'usage de la bicyclette.

Keywords: bicycle helmets, bicycling Injuries, bike lanes, bike share

\section{INTRODUCTION}

Bicycle helmets provide proven protection against head injuries. ${ }^{1-4}$ A 2009 Cochrane Review reported a $63 \%$ to $88 \%$ reduction in the risk of head, brain, and severe brain injury for all ages from bicycle helmet use. ${ }^{1}$

In 2012, the Office of the Chief Coroner for Ontario published a review of all cycling deaths in Ontario from 2006 to 2010, and noted that bicyclists whose cause of death included a head injury were three times less likely to be wearing a helmet than those who died of other types of injuries. ${ }^{5,6}$ A study of Ontario Coroner reports from 1986 to 1991 found that $75 \%$ of deaths in cycling were associated with head injury, and only $4 \%$ of these cyclists were wearing a helmet. ${ }^{7}$

Public bike-share programs (PBSPs) are broadly used around the world, with 49 countries hosting advanced programs in more than 500 cities, for a combined fleet of over 500,000 bicycles. ${ }^{8,9}$ These programs increase bicycling accessibility for commuters in the downtown core of cities. ${ }^{10}$ By facilitating one-way travel, public bike-sharing facilitates greater bicycle usage and has been found to reduce the use of personal automobiles and taxis. ${ }^{11}$ In Canada, PBSPs have been established in Montreal, Toronto, and Ottawa. The Toronto PBSP was established in 2011 by Bixi and involves 1,000 bicycles at 80 solar-powered docking stations. Management of the Toronto bike-share program was transferred to the Toronto Parking Authority in December 2014. Cyclists who are eighteen years of age or older can subscribe through a daily, 72-hour, monthly, or yearly fee, and obtain bicycles using their credit card or an electronic key fob at a docking station. The system has been used for over one million bike trips since its inception.

Helmet use among bike-share riders remains low. An observational study of helmet use in Toronto found that the proportion of PBSP bike riders using helmets was significantly lower than the proportion of helmet users on personal bikes (20.9\% vs $51.7 \%) .{ }^{12} \mathrm{~A}$ similar study conducted in Washington, DC and Boston, MA found that bike-share users were less likely to wear a helmet compared to personal bike users $(54.5 \%$ vs $80.8 \%) .{ }^{13}$ In Montreal, the prevalence of helmet use among bike-share users is only $12 \% .{ }^{14}$ There is increasing evidence suggesting that low prevalence of helmet use amongst PBSP users arises from the often spontaneous nature of public bicycle use, and the fact that few bike-share systems have readily available helmet rental options., ${ }^{2,14-19}$

An analysis of trauma centre data for bicycle-related injuries for five cities with PBSPs and five comparison cities reported an increase in the proportion of head injuries among bicycle-related injuries in the twelve months following implementation of PBSP. However, aggregate annual injuries were found to decline in bikeshare cities, even as they remained approximately the same in non-share cities. ${ }^{20,21}$ Proposed reasons included a relative decrease in the incidence of injuries as cycling ridership increased in cities (the "safety in numbers effect"), and the fact that bike-share cities tended to build better cycling infrastructure. ${ }^{21}$ In a modeling study of the London bike-sharing scheme, Woodcock and colleagues found that injury risks were lower among bike-share users compared with the average for cyclists in the same area. ${ }^{22}$

To better understand helmet use by PBSP users, we sought to characterize helmet-use patterns, barriers to helmet use, and cycling safety practices among bike-share users in Toronto. We used a case-control methodology to characterize and contrast PBSP users who wear helmets and those who do not. Secondary objectives included characterizing impressions regarding means to increase helmet usage, including helmet rental or sharing at PBSP, and legislation to enforce helmet use. 


\section{METHODS}

\section{Study design}

This was a case-control study of Toronto PBSP users (aged 18 or older). Study subjects were PBSP bike users wearing helmets at pre-chosen high-use PBSP stations. The control subjects were the next two non-helmeted PBSP station users. This strategy matched for location, time of day, day of week, and road and weather conditions.

Data were collected with an intercept survey at specified Toronto PBSP stations. Stations were selected in a structured manner, targeting higher-use PBSP sites, with a goal toward coverage of at least half of the 80 Toronto PBSP sites over the course of the study. We numbered each PBSP station and randomly selected sequential sites for data collection. If there was a low volume of cyclists or PBSP docks at a given site, then that site would not be used for subsequent data-collection periods.

A trained observer stood at each PBSP bike station, approximately three metres away from the rental podium. The surveyor approached a patron returning or accessing a bike at the PBSP station, identified himself or herself as a researcher associated with University of Toronto and University Health Network, and solicited participation in a five-minute research survey. If the respondent agreed, they were asked to read a consent form, and then were administered a standardized survey. Candidates were excluded from the study if they declined to participate, were unable to provide informed consent due to language barrier, or were younger than age eighteen.

\section{Piloting}

A pilot study of the survey and methodology, consisting of three, three-hour sessions of data collection, was completed, and questions were subsequently refined for clarity, prior to finalization and launch of the study. The survey included sections on cyclist demographics, helmet use, and cycling practices, and impressions regarding proposed interventions to improve helmet use on bike-share. (See Appendix A).

\section{Outcome measures}

The primary outcome was a characterization and comparison of helmet wearing (HW) and non-helmet wearing (NHW) bike-share users by usual helmet use, cycling practices, and socioeconomic factors.
Secondary outcomes included PBSP user impressions of proposed interventions to improve helmet use, including legislation and loaner helmets.

\section{Statistical analysis}

Analyses employed independent samples $t$-tests, $\chi^{2}$-tests, and Fischer's exact tests, as appropriate, and were performed using SAS and STATA. In cases where the question response was ordinal Wilcoxon two-sample tests (excluding the $\mathrm{n} / \mathrm{a}$ respondents) were performed.

A sample size calculation indicated that an $n$ of 300 participants (1:2 case:control ratio) would provide $>90 \%$ power to detect a $20 \%$ difference in HW practices and daily versus annual use subscription patterns at an alpha level of 0.05 .

\section{Ethics}

This study was approved by the University Health Network Research Ethics Board.

\section{RESULTS}

Surveys were completed for 545 unique users (433 males [79\%] and 112 females [21\%]) at 48 locations, from November 2012 to August 2013. We surveyed on 82 weekdays, one weekend day, and no holidays. Control matching ( $1 \mathrm{HW}$ to $2 \mathrm{NHW}$ ) was maintained as per protocol (180 HW and $365 \mathrm{NHW})$.

\section{Gender and socioeconomic status}

A higher proportion of females wore helmets (F: $41.1 \%, M: 30.9 \%, p=0.042$ ). NHWs tended to be slightly younger than HWs (NHW mean and median age: $34.4,32.0$ years vs $\mathrm{HW} 37.3,34.5, p=0.002$ ). Groups did not differ by employment status, education, or income. (Table 1).

Total household income was greater than $\$ 75,000$ for $80 \%$ of participants, and $91 \%$ had an undergraduate degree or graduate degree (masters or doctorate). A slightly higher proportion of HWs spoke English at home $(92.2 \%)$ versus NHWs $(86.3 \%) p=0.044$.

\section{Bicycle and helmet ownership}

Personal bicycle ownership and helmet ownership were lower among NHWs, though the majority of NHWs owned helmets (Table 2). 


\begin{tabular}{|c|c|c|c|c|}
\hline Demographic variable & Wearing Helmet \% (n) & Not Wearing Helmet \% (n) & Total \% (n) & p-value \\
\hline Gender & & & & $p=0.042$ \\
\hline Male & $74.4 \%(134)$ & $81.9 \%(299)$ & $79.5 \%(433)$ & \\
\hline Female & $25.6 \%(46)$ & $18.1 \%(66)$ & $20.6 \%(112)$ & \\
\hline Age in years (mean, median) & $37.3,34.5$ & $34.4,32.0$ & & $p=0.002$ \\
\hline Education (highest level) & & & & $p=0.474^{*}$ \\
\hline Primary school & $0.0 \%(0)$ & $0.0 \%(0)$ & $0.0 \%(0)$ & \\
\hline High school & $2.8 \%(5)$ & $4.4 \%(16)$ & $3.9 \%(21)$ & \\
\hline Some undergraduate & $3.9 \%(7)$ & $5.5 \%(20)$ & $5.0 \%(27)$ & \\
\hline Undergraduate degree & $52.5 \%(95)$ & $51.4 \%(186)$ & $51.6 \%(281)$ & \\
\hline MD & $2.8 \%(5)$ & $1.9 \%(7)$ & $2.2 \%(12)$ & \\
\hline DDS & $0.0 \%(0)$ & $0.0 \%(0)$ & $0.0 \%(0)$ & \\
\hline LLB & $1.1 \%(2)$ & $2.8 \%(10)$ & $2.2 \%(12)$ & \\
\hline DVM & $0.0 \%(0)$ & $0.0 \%(0)$ & $0.0 \%(0)$ & \\
\hline OD & $0.0 \%(0)$ & $0.0 \%(0)$ & $0.0 \%(0)$ & \\
\hline Masters & $31.7 \%(57)$ & $28.5 \%(103)$ & $39.8 \%(162)$ & \\
\hline Doctorate & $3.9 \%(7)$ & $5.8 \%(21)$ & $5.21(28)$ & \\
\hline Decline & $1.1 \%(2)$ & $0.6 \%(2)$ & $0.7 \%(4)$ & \\
\hline Employment Status & & & & $p=0.291^{* *}$ \\
\hline Student & $5.6 \%(10)$ & $9.4 \%(34)$ & $8.1 \%(44)$ & \\
\hline Homemaker & $0.0 \%(0)$ & $0.0 \%(0)$ & $0.0 \%(0)$ & \\
\hline Unemployed, seeking work & $1.1 \%(2)$ & $0.3 \%(1)$ & $0.6 \%(3)$ & \\
\hline On disability & $0.0 \%(0)$ & $0.0 \%(0)$ & $0.0 \%(0)$ & \\
\hline On parental leave & $0.0 \%(0)$ & $0.0 \%(0)$ & $0.0 \%(0)$ & \\
\hline Self-employed & $1.7 \%(3)$ & $2.5 \%(9)$ & $2.2 \%(12)$ & \\
\hline Part-time employed & $3.3 \%(6)$ & $2.5 \%(9)$ & $2.7 \%(15)$ & \\
\hline Full-time employed & $87.2 \%(157)$ & $85.4 \%(309)$ & $85.5 \%(466)$ & \\
\hline Retired & $0.0 \%(0)$ & $0.3 \%(1)$ & $0.2 \%(1)$ & \\
\hline Decline & $1.1 \%(2)$ & $0.6 \%(2)$ & $0.7 \%(4)$ & \\
\hline Other & $0.6 \%(1)$ & $0.0 \%(0)$ & $0.2 \%(1)$ & \\
\hline
\end{tabular}

\section{Helmet use on personal and bike share bicycles}

NHWs were less likely to always wear a helmet when on their own bicycle than HWs (NHW: $22.2 \%$ vs HW: $66.7 \%, p<0.001$ ), and less likely to wear a helmet always or most of the time when on PBSP (NHW: $5.8 \%$ vs HW: $92.3 \%, p<0.001$ ).

\section{Planned versus unplanned bike-share use and helmet practice}

Both groups, but more HWs, had planned to use PBSP when leaving their houses. The main trip purpose in both groups was to get to work (HW: $88.3 \%$ vs NHW: $84.1 \%, p=0.19)$. Both groups were primarily one-year subscribers (NHW: $85.2 \%$ vs HW: $95.6 \%$ ).

\section{Sporadic users (i.e., 24-hour plan)}

Sporadic users were a small minority of those surveyed. NHWs were more likely to use the 24-hour plan than HWs (NHW: $12.1 \%$ vs HW: $2.2 \%, p=0.0003$ ). NHWs were more likely to be biking for social or entertainment purposes than HWs $(6.0 \%$ NHW vs $0.0 \% \mathrm{HW}, p<0.001)$.

\section{Barriers to helmet use}

NHWs were more likely than HWs to cite helmets as inconvenient ( $64.7 \%$ vs $21.7 \%)$, unnecessary ( $11.2 \%$ vs $1.2 \%)$, or lack of ownership (19.7\% vs $0.6 \%)$ as their primary barriers to helmet use (all $p<0.001)$. 


\begin{tabular}{|c|c|c|c|c|}
\hline Survey Question and Response & $\begin{array}{l}\text { Wearing } \\
\text { Helmet \% (n) }\end{array}$ & $\begin{array}{l}\text { Not Wearing } \\
\text { Helmet \% (n) }\end{array}$ & Total [\% (n)] & $p$ value $(n)$ \\
\hline Do you own a bike helmet? & & & & $n=544, p<0.001$ \\
\hline Yes & $99.4 \%(179)$ & $62.4 \%(227)$ & $74.6 \%(406)$ & \\
\hline No & $0.6 \%(1)$ & $37.6 \%(137)$ & $25.4 \%(138)$ & \\
\hline Do you own a bike? & & & & $n=545, p=0.003$ \\
\hline Yes & $78.3 \%(141)$ & $65.8 \%(240)$ & $69.9 \%(381)$ & \\
\hline No & $21.7 \%(39)$ & $34.3 \%(125)$ & $30.1 \%(164)$ & \\
\hline $\begin{array}{l}\text { How often do you wear a helmet when you cycle on your own } \\
\text { bike? }\end{array}$ & & & & $n=545, p<0.001$ \\
\hline Always & $66.7 \%(120)$ & $22.2 \%(81)$ & $36.9 \%(201)$ & \\
\hline Most of the time & $14.4 \%(26)$ & $11.0 \%(40)$ & $12.1 \%(66)$ & \\
\hline Sometimes & $2.2 \%(4)$ & $8.5 \%(31)$ & $6.4 \%(35)$ & \\
\hline Rarely & $1.1 \%(2)$ & $6.3 \%(23)$ & $4.6 \%(25)$ & \\
\hline Never & $0.6 \%(1)$ & $23.8 \%(87)$ & $16.2 \%(88)$ & \\
\hline I don't own a bike & $15.0 \%(27)$ & $28.2 \%(103)$ & $23.9 \%(130)$ & \\
\hline How often do you wear a helmet when you cycle on bike-share? & & & & $n=545, p<0.001$ \\
\hline Always & $60.6 \%(109)$ & $0.0 \%(0)$ & $20.0 \%(109)$ & \\
\hline Most of the time & $31.7 \%(57)$ & $5.8 \%(21)$ & $14.3 \%(78)$ & \\
\hline Sometimes & $3.3 \%(6)$ & $7.7 \%(28)$ & $6.2 \%(34)$ & \\
\hline Rarely & $1.7 \%(3)$ & $9.9 \%(36)$ & $7.2 \%(39)$ & \\
\hline Never & $2.8 \%(5)$ & $76.7 \%(280)$ & $52.3 \%(285)$ & \\
\hline $\begin{array}{l}\text { Did you plan on using bike-share when you left the house this } \\
\text { morning? }\end{array}$ & & & & $n=545, p<0.001$ \\
\hline Yes & $97.2 \%(175)$ & $85.2 \%(311)$ & $89.2 \%(486)$ & \\
\hline No & $1.7 \%(3)$ & $12.1 \%(44)$ & $8.6 \%(47)$ & \\
\hline Maybe & $1.1 \%(2)$ & $2.7 \%(10)$ & $2.2 \%(12)$ & \\
\hline
\end{tabular}

Table 3. How safe do you think cycling is in Toronto?

\begin{tabular}{lccc}
\hline Safety Question Response* & Wearing Helmet \% (n) & Not Wearing Helmet \% (n) & Total Responses \% (n) \\
\hline Very safe & $5.6 \%(10)$ & $11.8 \%(43)$ & $9.7 \%(55)$ \\
Somewhat safe & $45.6 \%(82)$ & $45.8 \%(167)$ & $45.7 \%(249)$ \\
Neither safe nor dangerous & $11.7 \%(21)$ & $8.5 \%(31)$ & $9.5 \%(52)$ \\
Somewhat dangerous & $32.8 \%(59)$ & $27.4 \%(100)$ & $29.2 \%(159)$ \\
Very dangerous & $4.4 \%(8)$ & $6.6 \%(24)$ & $5.9 \%(32)$ \\
\hline *For the safety question responses: $\chi^{2}=8.21, \mathrm{df}=4, p=0.084$, Wilcoxon test: $p=0.128$. & & \\
\hline
\end{tabular}

\section{Safety practice and injury experience}

HWs and NHWs did not differ in their view of the safety of cycling in Toronto. $\left(\chi^{2}=8.21, \mathrm{df}=4\right.$, $p=0.084$, Wilcoxon test: $p=0.128$ ). (See Table 3.)

The proportion of subjects who had been in an accident on their personal bicycle did not differ across study groups $(p=0.663)$. Reported accidents on bike-share were uncommon. However, HWs were almost twice as likely to report having been in a cycling accident on PBSP in the past 12 months $(8.9 \%$ vs $4.9 \%, p=0.072)$.

\section{Impact of proposed remedies to improve helmet use}

NHWs were more likely to report that they would wear a helmet more $(61.4 \%$ NHW vs $13.9 \% \mathrm{HW}, p<0.001)$, and/or cycle less $(22.5 \%$ NHW vs $4.4 \% \mathrm{HW}, p<0.001)$ if helmet use was mandatory. HWs were more likely to report that their cycling and helmet use behavior would not change (82.8\% HW vs $19.7 \%$ NHW, $p<0.001)$ (Table 4).

Approximately half of NHWs indicated they would use loaner helmets if these were available at PBSP stations (28.8\% very likely, $24.7 \%$ likely). 


\begin{tabular}{|c|c|c|c|c|c|}
\hline Impact of law & $\begin{array}{c}\text { Wearing } \\
\text { Helmet \% (n) }\end{array}$ & $\begin{array}{l}\text { Not Wearing } \\
\text { Helmet \% (n) }\end{array}$ & $\begin{array}{c}\text { Total } \\
\text { Responses \% (n)* }\end{array}$ & Test Used & $p$-value \\
\hline I would wear a helmet more often & $13.9 \%(25)$ & $61.4 \%(224)$ & $45.7 \%(249)$ & chi-sq $=109.5, \mathrm{df}=1$ & $p<0.001$ \\
\hline No change & $82.8 \%(149)$ & $19.7 \%(72)$ & $40.6 \%(221)$ & chi-sq $=198.8, \mathrm{df}=1$ & $p<0.001$ \\
\hline I would wear a helmet less often & $0.0 \%(0)$ & $0.3 \%(1)$ & $0.2 \%(1)$ & Fisher's exact test & $p=1.0$ \\
\hline I would cycle less & $4.4 \%(8)$ & $22.5 \%(82)$ & $16.5 \%(90)$ & chi-sq $=28.4, d f=1$ & $p<0.001$ \\
\hline I would cycle more & $0.0 \%(0)$ & $0.0 \%(0)$ & $0.0 \%(0)$ & $\mathrm{n} / \mathrm{a}$ & $\mathrm{n} / \mathrm{a}$ \\
\hline Other & $0.0 \%(0)$ & $0.3 \%(1)$ & $0.2 \%(1)$ & Fisher's exact test & $p=1.0$ \\
\hline
\end{tabular}

\section{DISCUSSION}

\section{Deliberate decisions versus forgetfulness}

We used a case-control methodology to characterize Toronto bike-share users based on their use or non-use of helmets. Our results suggest that cyclists make very deliberate decisions regarding helmet use. Individuals who did not wear helmets on bike share also reported that they generally chose not to wear helmets on their own bicycles, despite the fact that $62 \%$ of them owned a helmet. The great majority of participants were regular PBSP subscribers using bike-share as part of their commute to work, and had planned to use bike-share prior to leaving their homes. This suggests that not wearing a helmet is related to intentional choice, rather than forgetfulness.

\section{Demographics}

Study participants were predominantly male, educated, and affluent. The gender distribution we found is similar to that reported in other cities and in a previous study of Toronto bike-share users. ${ }^{12}$ In 2011-2012, Shaheen and colleagues undertook a public bike sharing study in four North American cities: Montréal, Minneapolis-St. Paul, Toronto, and Washington DC. Bike sharing members had slightly higher incomes, were younger than the general population (though with a significant proportion middle-aged or older), were predominantly male, and were more educated, than the general population. ${ }^{23,24}$

We found males and younger riders were significantly associated with lower helmet use and that HW practices did not differ by employment status, education, or income. Several Canadian studies have reported that cyclists who do not wear helmets tend to be younger, less affluent, and less educated than those who do wear helmets. ${ }^{25-27}$ Recreational cyclists have been reported to be less likely to wear a helmet than commuter cyclists. ${ }^{26}$ In our study, cyclists not wearing helmets were only marginally more likely to be biking for social or entertainment purposes than HWs, though these purposes were uncommon in both groups surveyed.

We found reported cycling injuries were few in number, but the proportion of those reporting injuries in HWs was almost twice that in NHWs. A cross-sectional study involving university students found that prior bicycling injury is associated with increase in bicycle helmet use, especially if hospitalization occurred. ${ }^{25}$

\section{Barriers to bicycle helmet use}

Approximately two-thirds of NHWs reported owning a personal bicycle or a helmet. The primary barriers to bicycle helmet use cited by NHWs in our study were inconvenience, perceived lack of necessity, and lack of ownership. Similar barriers to helmet use have been reported elsewhere. ${ }^{28-35}$

\section{Approaches to increasing helmet use}

Approaches to improving helmet use include consumer incentives, education surrounding helmet safety, and legislation. Consumer incentives can include helmet rentals, coupons, mailings at point of sale, discounts and promotion, and loaner helmets. For example, the Melbourne, Australia PBSP instituted courtesy helmets as a permanent feature of their service, with loaner helmets available free of charge with each bicycle, and the Boston PBSP employs high-capacity, solar-powered helmet rental vending machines (HelmetHub) that dispense sanitized loaner helmets that can be returned at point of origin or destination. 
Educational campaigns have been shown to be effective in increasing helmet use, and can be significantly influenced by peer helmet use among children, adolescents, and adults. ${ }^{33,34}$ Public health campaigns could target the young male demographic, and stress the comfort, lightweight design, styling, and low cost of contemporary helmets. Vulcan and colleagues reported 10 years of helmet-use promotion in Australia from 1980 through to institution of compulsory helmet use in 1990, with initiatives that included bicycle education in schools, mass media publicity, professional organization support, community group support, bulk purchase schemes, and government rebates. During this period, voluntary helmet use increased from $2 \%$ to $20 \%$ in secondary students, and from $27 \%$ to $40 \%$ in adults. ${ }^{36}$

\section{Legislation}

In our study, cyclists on bike-share who did not wear helmets anticipated they would have greater helmet use if helmet legislation were enacted. Approximately one-fifth indicated that they would cycle less if helmet legislation was enacted.

In North American jurisdictions, the typical proportions of adults wearing helmets is in the range of $30 \%$ to $50 \%$ where there is no requirement, and over $70 \%$ where legislation requires use by adults. ${ }^{28,37}$

Legislation has been found to effectively increase helmet use and decrease head injury rates. ${ }^{38,39}$ After introduction of helmet laws in Victoria, Australia, helmet use increased from $31 \%$ to $75 \%$, and cycling fatalities decreased by $48 \%{ }^{36,40}$ A 2010 Canadian study found that youth and adults were significantly more likely to wear helmets as the comprehensiveness of helmet legislation increased, and that helmet legislation was not associated with changes in ridership. ${ }^{37}$ However, these studies did not expressly investigate PBSP ridership.

Legislation mandating helmet use for all cyclists (or cyclists under a certain age) has been enacted in six of ten Canadian provinces, parts of the United States, and many other countries including Australia, New Zealand, Europe (including Czech Republic, Slovenia, Spain, Malta, Finland, Sweden, Iceland) and Japan. The Canadian Association of Emergency Physicians recently published a position statement on bicycle safety that made a number of evidence-based suggestions, and called for Canada-wide legislation requiring bicycle helmets for all ages, along with an educational campaign regarding cyclist visibility, and governmental prioritization of a "complete streets" approach to the environment for cyclists. ${ }^{41}$

Opponents to helmet legislation typically express concerns such as invasion of personal freedoms. Moreover, they stress the relatively low morbidity and mortality associated with cycling ${ }^{42}$ and argue that mandatory helmet legislation unfairly shifts the burden of responsibility for serious cycling collisions from motorists to cyclists. Mandatory helmet legislation may be the most easily enacted policies aimed at improving cycling safety; however, opponents often tout the low incidence of head injuries in European countries where helmets are generally not worn but where cycling infrastructure is a core component of better-designed and more extensive urban planning. Mandatory helmet opponents often express concerns about the impact on ridership, citing the reported negative impact on public bike-share use in Victoria, Australia in the two years following the introduction of PBSP. ${ }^{36,40}$ Of note, Mexico City repealed its mandatory helmet law in 2010, the same year that the city launched its first public bike system. $^{43}$

\section{Limitations}

Since the Toronto PBSP's main use is facilitating transportation over short distances and the majority of bicycling traffic is during peak commuter traffic hours, we chose to survey during these peak periods $(0700$ 1000 and 1500-1800) to maximize the availability of eligible participants. By interviewing primarily on weekdays during commuting hours, our approach may have failed to capture those who use bike-share primarily for pleasure or unplanned trips. However, in a prior study of four North American cities, the most common trip purpose was work or school-related. ${ }^{23,24}$ Structured sampling of PBSP stations may have further led to a non-representative population of Toronto bike-share users. When soliciting for participation in the study, if someone refused, we continued to recruit to maintain the 2:1 ratio during that survey period. However, we did not track refusal rates or reasons for refusal during the study. Reponses to hypothetical questions (such as those regarding proposed legislation or loaner helmets) might not necessarily translate into actual practice. Questions regarding cycling accidents only queried the most recent twelve months, and it is possible that respondents might have been influenced by injuries or near misses that had 
occurred in the more remote past. While the demography of PBSP users in our study is similar to that reported in other North American studies, our results are not necessarily generalizable to other regions.

\section{CONCLUSIONS}

PBSP users surveyed appear to make deliberate decisions regarding helmet use. NHWs tended to be male, slightly younger, and less likely to use helmets on their personal bicycles. As Toronto cyclists who do not wear helmets on PBSP generally do not wear helmets on their personal bicycles, interventions to increase helmet use should target both personal and bike-share users. Legislating helmet use and provision of rental helmets could improve helmet use among bike-share users, but our results suggest some risk of reduced cycling with legislation.

Competing Interests: None declared.

\section{SUPPLEMENTARY MATERIAL}

To view Supplementary Material for this article, please visit http://dx.doi.org/10.1017/cem.2015.22

\section{REFERENCES}

1. Thompson DC, Rivara FP, Thompson R. Helmets for preventing head and facial injuries in bicyclists. Cochrane Database Syst Rev 2000:CD001855, doi:10.1002/14651858. cd001855.

2. Attewell RG, Glase K, McFadden M. Bicycle helmet efficacy: a meta-analysis. Accid Anal Prev 2001;33(3):345-52.

3. Rivara FP, Thompson DC, Thompson RS. Epidemiology of bicycle injuries and risk factors for serious injury. Inj Prev 1997;3(2):110-4.

4. Thompson DC RF, Thompson R. Wearing a helmet dramatically reduces the risk of head and facial injuries for bicyclists involved in a crash, even if it involves a motor vehicle. Cochrane Database of Systematic Reviews: The Cochrane Collaboration; 2009. Available at: http://www. ncbi.nlm.nih.gov/pubmedhealth/PMH0011225/ (accessed 1 September 2014).

5. Office of the Chief Coroner of Ontario. Cycling Death Review. Toronto, ON: Ministry of Community Safety and Correctional Services; 2012. Available at: http://www.mcscs. jus.gov.on.ca/english/DeathInvestigations/office_coroner/ PublicationsandReports/CyclingDeathReview/DI_Cycling Death_Review.html (accessed 1 September 2014).

6. Persaud N, Coleman E, Zwolakowski D, et al. Nonuse of bicycle helmets and risk of fatal head injury: a proportional mortality, case-control study. CMA7 2012;184(17):921-3.
7. Rowe BH, Rowe AM, Bota GW. Bicyclist and environmental factors associated with fatal bicycle-related trauma in Ontario. CMA7 1995;152(1):45-53.

8. Shaheen S, Guzman S, Zhang H. Bikesharing in Europe, the Americas, and Asia: Past, Present, and Future. Richmond, CA: UC Davis: Institute of Transportation Studies (UCD); 2010. Available at: https://escholarship.org/uc/item/79v822k5 (accessed 12 December 2014).

9. Larsen J. Bike-Sharing Programs Hit the Streets in Over 500 Cities Worldwide. Plan B Updates. Washington, DC: Earth Policy Institute; 2013. Available at: http://www.earthpolicy.org/plan_b_updates/2013/update112 (accessed 12 December 2014).

10. Fuller D, Gauvin L, Kestens Y, et al. Use of a new public bicycle share program in Montreal, Canada. Am 7 Prev Med 2011;41(1):80-3.

11. Martin EW, Shaheen SA. Evaluating public transit modal shift dynamics in response to bikesharing: a tale of two U.S. cities. 7 Transp Geog 2014;41:315-24.

12. Bonyun M, Camden A, Macarthur C, et al. Helmet use in BIXI cyclists in Toronto, Canada: an observational study. BM7 Open 2012;2(3):e001049.

13. Fischer CM, Sanchez CE, Pittman M, et al. Prevalence of bicycle helmet use by users of public bikeshare programs. Ann Emerg Med 2012;60(2):228-31.

14. Grenier T, Deckelbaum DL, Boulva K, et al. A descriptive study of bicycle helmet use in Montreal, 2011. Can 7 Public Health 2013;104(5):e400-4.

15. Kraemer JD, Roffenbender JS, Anderko L. Helmet wearing among users of a public bicycle-sharing program in the District of Columbia and comparable riders on personal bicycles. Am 7 Public Health 2012;102(8):e23-5.

16. Fishman E, Washington S, Haworth N. Barriers and facilitators to public bicycle scheme use: A qualitative approach. Transp Res Part F Traffic Psychol Behav 2012; 15(6):686-98.

17. Fishman E, Washington S, Haworth N. Bike share: a synthesis of the literature. Transport Reviews 2013;33(2):148-65.

18. Page JL, Macpherson AK, Middaugh-Bonney $\mathrm{T}$, et al. Prevalence of helmet use by users of bicycles, push scooters, inline skates and skateboards in Toronto and the surrounding area in the absence of comprehensive legislation: an observational study. Inj Prev 2012;18(2):94-7, doi:10.1136/injuryprev-2011-040029.

19. Basch CH, Zagnit EA, Rajan S, et al. Helmet use among cyclists in New York City. 7 Community Health 2014;39 (5):956-8, doi:10.1007/s10900-014-9836-8.

20. Graves JM, Pless B, Moore L, et al. Public bicycle share programs and head injuries. Am 7 Public Health 2014;104(8): e106-11, doi:10.2105/ajph.2014.302012.

21. Jaffe E. Head Injuries Didn't Rise in Bike-Share Cities. They Actually Fell. City Lab. Washington, DC: Atlantic Media; 2014. Available at: http://www.citylab.com/commute/ 2014/06/head-injuries-didnt-rise-in-bike-share-cities-theyactually-fell/372811/ (accessed 12 December 2014).

22. Woodcock J, Tainio M, Cheshire J, et al. Health effects of the London bicycle sharing system: health impact modelling study. BMF 2014;348:g425, doi:10.1136/bmj. $\mathrm{g} 425$. 
23. Shaheen SA, Martin EW, Cohen AP, et al. Public Bikesharing in North America: Early Operator and User Understanding. San Jose, CA: Mineta Transportation Institute; 2012. Available at: http://transweb.sjsu.edu/ PDFs/research/1029-public-bikesharing-understanding-earlyoperators-users.pdf (accessed 1 September 2014).

24. Shaheen SA, Martin EW, Cohen AP. Public Bikesharing and Modal Shift Behavior: A Comparative Study of Early Bikesharing Systems in North America. Int 7 Transp 2013; 1(1):35-54, doi:10.14257/ijt.2013.1.1.03.

25. Teschke K, Brubacher JR, Friedman SM, et al. Personal and trip characteristics associated with safety equipment use by injured adult bicyclists: a cross-sectional study. BMC Public Health 2012;12:765, doi:10.1186/1471-2458-12-765.

26. Irvine $\mathrm{A}$, Rowe $\mathrm{BH}$, Sahai $\mathrm{V}$. Bicycle helmet-wearing variation and associated factors in Ontario teenagers and adults. Can 7 Public Health 2002;93(5):368-73.

27. Li G, Baker SP, Smialek JE, et al. Use of alcohol as a risk factor for bicycling injury. 7AMA 2001;285(7):893-6.

28. Rodriguez G, Quintero A. Attitudes and knowledge toward bicycle helmet by school age children. Bol Asoc Med P R 1992;84(11):305-8.

29. Klein KS, Thompson D, Scheidt PC, et al. Factors associated with bicycle helmet use among young adolescents in a multinational sample. Inj Prev 2005;11(5):288-93, doi:10.1136/ip.2004.007013.

30. Ashbaugh SJ, Macknin ML, VanderBrug Medendorp S. The Ohio Bicycle Injury Study. Clin Pediatr (Phila) 1995; 34(5):256-60.

31. Joshi MS, Beckett K, Macfarlane A. Cycle helmet wearing in teenagers-do health beliefs influence behaviour? Arch Dis Child 1994;71(6):536-9.

32. Seijts GH, Kok G, Bouter LM, et al. Barriers to wearing bicycle safety helmets in The Netherlands. Arch Pediatr Adolesc Med 1995;149(2):174-80.

33. Finnoff JT, Laskowski ER, Altman KL, et al. Barriers to bicycle helmet use. Pediatrics 2001;108(1):E4.
34. DiGuiseppi CG, Rivara FP, Koepsell TD, et al. Bicycle helmet use by children. Evaluation of a community-wide helmet campaign. $7 A M A$ 1989;262(16):2256-61.

35. Villamor E, Hammer S, Martinez-Olaizola A. Barriers to bicycle helmet use among Dutch paediatricians. Child Care Health Dev 2008;34(6):743-7, doi:10.1111/j.13652214.2008.00882.x.

36. Vulcan AP, Cameron MH, Watson WL. Mandatory bicycle helmet use: experience in Victoria, Australia. World 7 Surg 1992;16(3):389-97.

37. Dennis J, Potter B, Ramsay T, et al. The effects of provincial bicycle helmet legislation on helmet use and bicycle ridership in Canada. Inj Prev 2010;16(4):219-24, doi:10.1136/ip.2009.025353.

38. Macpherson A, Spinks A. Bicycle helmet legislation for the uptake of helmet use and prevention of head injuries. Cochrane Database Syst Rev 2008;16(3):CD005401, doi:10.1002/14651858.CD005401.pub3.

39. Karkhaneh M, Kalenga JC, Hagel BE, et al. Effectiveness of bicycle helmet legislation to increase helmet use: a systematic review. Inj Prev 2006;12(2):76-82, doi:10.1136/ ip.2005.010942.

40. Cameron MH, Vulcan AP, Finch CF, et al. Mandatory bicycle helmet use following a decade of helmet promotion in Victoria, Australia-an evaluation. Accid Anal Prev 1994; 26(3):325-37.

41. Letovsky E, Rowe BH, Friedman SM, et al. Position Statement: Improving Bicyle Safety in Canada. C7EM 2015;17(3):323-7.

42. Wardlaw M. Assessing the actual risks faced by cyclists. Traffic Engineering and Control 2002:352-6. Available at: http://www.cyclehelmets.org/papers/c2014.pdf (accessed 1 September 2014).

43 Peñalosa A. Repeal of the helmet law in Mexico City. 2011. Available at: http://www.ecf.com/wp-content/uploads/2011/ 09/Mexico_City_Repeal_of_the_helmet_law.pdf (accessed 1 September 2014). 